Article abstract-We found an antinuclear antibody highly restricted to nuclei of neurons in two patients with subacute sensory neuronopathy complicating oat cell carcinoma of the lung. Serum was tested by indirect immunofluorescence and immunoperoxidase staining. At low concentrations of antibody, only the nuclei of the neurons were stained. At high concentrations, there was also staining of the nuclei of glial cells and fetal nonneural tissues. The cytoplasm of most neurons was stained with the immunoperoxidase method.

NEUROLOGY 1985;35:538-543

\title{
Neuronal antinuclear antibody in sensory neuronopathy from lung cancer
}

\author{
Francesc Graus, MD; Carlos Cordon-Cardo, MD, PhD; and Jerome B. Posner, MD
}

Subacute sensory neuronopathy (SSN), a "remote effect" of cancer, is usually associated with small cell carcinoma of the lung and is characterized by destruction of the neurons in the dorsal root ganglia (DRG), with occasional inflammatory infiltrates..$^{1.2}$ The course is subacute, with pain and dysesthesias, impairment of all sensation, and severe ataxia. Motor function is preserved or only modestly impaired. In some patients, however, there is more diffuse abnormality, with dementia, cranial nerve signs, or myelopathy, often associated with neuronal cell loss and perivascular inflammatory infiltrates in the hippocampus, brainstem, and spinal cord. ${ }^{2}$

The etiology is unknown. Viral studies have been uniformly negative. Wilkinson and Zeromsky ${ }^{3}$ and Zeromsky ${ }^{4}$ reported an antibody against the cytoplasmic components of the neurons of four patients with SSN, but others ${ }^{1.5}$ failed to confirm this finding. We now describe an antibody against neuronal nuclei in two patients with sensory neuronopathy and oat cell carcinoma of the lung.

Patients. The two patients were women in their 50s. In one patient, the tumor was discovered during evaluation for SSN, and in the other, SSN appeared just after discovery of the tumor on chest $\mathrm{x}$-ray, but before treatment began. SSN was characterized by pain, paresthesias, severe sensory ataxia, and absent deep tendon reflexes in all four limbs, with preserved strength. The symptoms progressed for about 1 month and have been stable since. One patient can walk with assistance; the second is bedridden. Both tumors had a good response to treatment, and both patients are free of evident cancer at 6 months. In both patients, myelography and CT of the head were normal. CSF was also normal, except for increased protein concentration $(158 \mathrm{mg} / \mathrm{dl})$ in one patient.

Antinuclear antibody tests done on a smear of mouse kidney were negative. Serum and CSF immunoglobulin levels were normal. EMG in one patient showed no denervation, but sensory action potentials of the sural, median, and ulnar nerves were absent, and there was a mild decrease in the motor conduction of the median $(45.1 \mathrm{~m} / \mathrm{sec})$, ulnar $(40 \mathrm{~m} /$ $\mathrm{sec})$, and peroneal $(35.1 \mathrm{~m} / \mathrm{sec})$ nerves. Neither patient responded to plasma exchange (three to five exchanges).

Materials and methods. Serum or plasma from both patients was kept frozen at $-70^{\circ} \mathrm{C}$ until used. Normal adult tissues for immunofluorescence or immunoperoxidase staining were obtained at autopsy within 12 hours of death or from surgical pathology specimens within 1 hour after resection. Human fetal tissues were obtained from elective abortions induced by prostaglandins. The fetuses ranged from 12 to 14 weeks' gestational age, as determined by crownheel, crown-rump, and weight measurements. Tissues were snap-frozen in isopentane chilled by liquid nitrogen, placed in OCT Compound (Miles, Naperville, IL), and stored at $-70^{\circ} \mathrm{C}$.

Indirect immunofluorescence (IIF). IIF was performed on $7-\mu \mathrm{m}$ tissue sections fixed in cold acetone and sequentially incubated with $10 \%$ normal goat serum for 15 minutes; serial dilutions of patient sera for 1 hour at room temperature; and goat antihuman IgG, IgM, IgA, kappa, or lambda conjugated with fluorescein isothiocyanate (FITC) for 30 minutes (Cappel, Cochranville, PA). Dilutions used were 1:100 for antihuman IgG and 1:40 for the others. After

From the Departments of Neurology and Pathology, Memorial Sloan-Kettering Cancer Center, Cornell University Medical College, New York, NY.

Presented in part at the thirty-sixth annual meeting of the American Academy of Neurology, Boston, MA, April 1984.

Address correspondence and reprint requests to Dr. Posner, 1275 York Avenue, New York, NY 10021. 


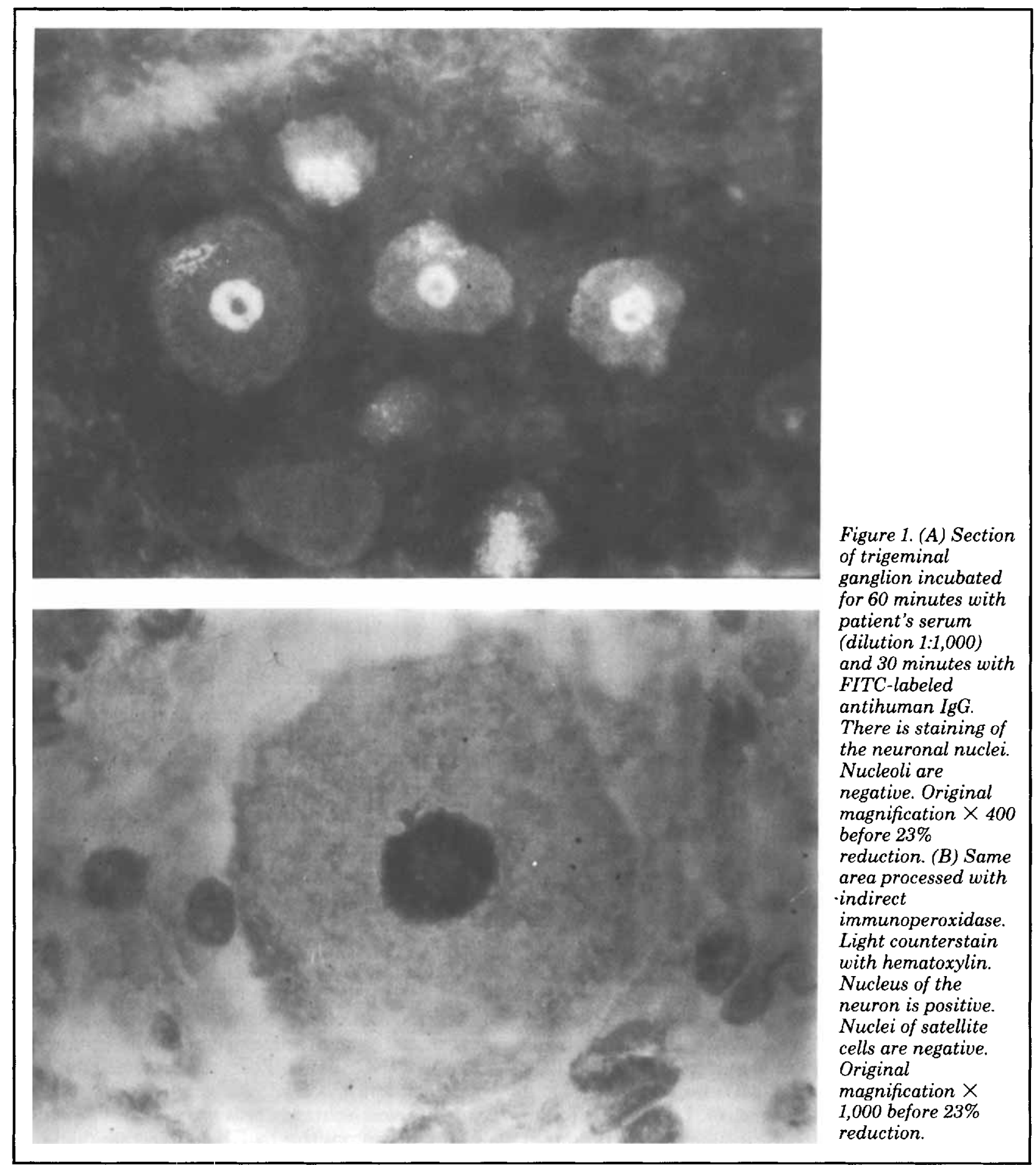

washing, slides were mounted in $90 \%$ glycerol in phosphate-buffered saline (PBS) and examined using a Nikon Optiphot fluorescence microscope with epiillumination (Nikon Inc., Garden City, NY).

For IIF testing for complement fixation, we used the patients' sera, previously heated for 30 minutes at $56{ }^{\circ} \mathrm{C}$ to inactivate the complement, followed by fresh normal (ANA-negative) human serum (dilution 1:10) for 30 minutes, and overlaid with goat antihuman $\mathrm{C}_{3}$ labeled with FITC (dilution 1:20) for 30 minutes (Cappel, Cochranville, PA).

Immunoperoxidase staining. For indirect immunoperoxidase technique, $7-\mu \mathrm{m}$ sections were stained in the following sequence: $0.3 \% \mathrm{H}_{2} \mathrm{O}_{2}$ for 15 minutes, $10 \%$ normal rabbit serum for 10 minutes, serial dilutions of patients' sera for 24 hours at $4{ }^{\circ} \mathrm{C}$, peroxidase-conjugated rabbit antihuman IgG (Dakopatts, Denmark) (dilution 1:100) for 30 minutes, and $0.05 \%$ 


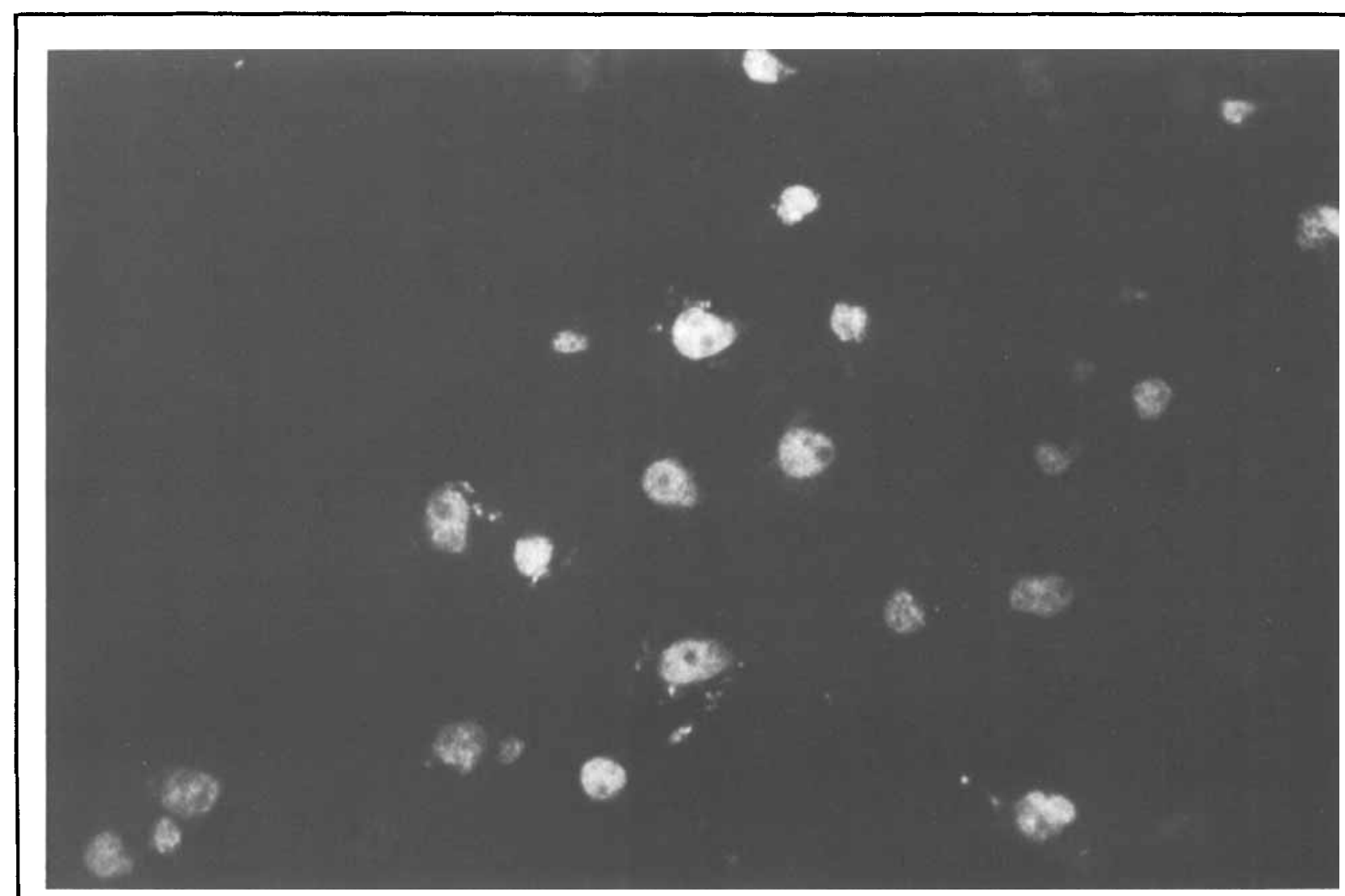

Figure 2. (A) Section of frontal cortex processed as in figure 1A. Nuclei of neurons are positive with a homogeneous pattern. Original magnification $\times 400$ before $3 \%$ reduction. (B) Section of cerebellum incubated overnight with patient's serum (dilution 1:4,000) and processed with immunoperoxidase. Light counterstain with hematoxylin. Nuclei of Purkinje and granular cell layers are positive. Cytoplasm of Purkinje cell is weakly positive. Original magnification $\times 400$ before $31 \%$ reduction.

diaminobenzidine tetrahydrochloride and $0.01 \%$ $\mathrm{H}_{2} \mathrm{O}_{2}$ for 6 minutes. Some sections were lightly counterstained with hematoxylin.

Study of antigen characteristics. For a preliminary study of the nature of the antigen, acetone-fixed $7-\mu \mathrm{m}$ tissue sections were pretreated with absolute alcohol for 30 minutes, xylene for 15 minutes, heating at 60 and $100{ }^{\circ} \mathrm{C}$ for 15 minutes, $0.1 \mathrm{~N} \mathrm{HCl}$ for 30 minutes, pronase $(1.5 \mathrm{mg} / \mathrm{ml}$ ) (Calbiochem-Behring Corp., La Jolla, CA) for 4 minutes, DNase I (200 $\mu \mathrm{g} / \mathrm{ml}$ ) (Sigma, St. Louis, $\mathrm{MO}$ ) for 30 minutes, and RNase A $(200 \mu \mathrm{g} / \mathrm{ml}$ ) (Sigma, St. Louis, MO) for 30 minutes. RNase and DNase incubations were done at $37{ }^{\circ} \mathrm{C}$. DNase was diluted in PBS containing 100 $\mu \mathrm{g} / \mathrm{ml}$ of $\mathrm{MgCl}_{2}$ and $\mathrm{CaCl}_{2}$. After pretreatment, sections were stained by regular IIF. Controls without pretreatment were always tested, and reference sera were used to evaluate the specificity of the digestion in the case of enzymatic pretreatments. Counterimmunoelectrophoresis was performed ${ }^{6}$ to compare the serum of both patients, with reference sera for $\mathrm{Sm}, \mathrm{nRNP}, \mathrm{Ro}$, and La antinuclear antibodies.

Absorption tests. The serum of both patients (dilution 1:50) was absorbed for 24 hours at $4{ }^{\circ} \mathrm{C}$ with acetone powder of mouse liver ( $10 \mathrm{mg} / \mathrm{ml}$ of serum), with acid-extracted histones from human brain and liver $(1 \mathrm{mg} / \mathrm{ml})$, and with a nuclear-rich pellet obtained from homogenization of fresh human cerebral cortex in $2.0 \mathrm{M}$ sucrose containing $1 \mathrm{mmol} \mathrm{MgCl}_{2}$ $(20 \% \mathrm{w} / \mathrm{v})$ and centrifugation of the homogenate at $64,000 \mathrm{~g}$ for 30 minutes in an $\mathrm{SW} 41$ rotor. $^{7}$

Results. Serum from both patients tested on DRG or trigeminal ganglia sections gave a bright staining of the nuclei of the neurons. The nuclear pattern was homogeneous, and the nucleolus was negative. Nuclei of satellite and Schwann cells were negative (figure 1). Staining was positive by IIF up to serum dilutions of 1:800 and 1:4,000. Serum titers dropped by one-half in both patients after a single plasmapheresis.

Distribution of antibody reactivity. Both sera were positive, with the same nuclear pattern in nuclei of neurons of all the different areas of the brain tested (cortex, hippocampus, putamen, thalamus, hypothalamus, mesencephalon, basis and tegmentum pontis, medulla, cerebellum, dentate nucleus, and spinal cord) (figure 2) at the same titers found in the DRG neurons. The pineal gland and the photoreceptor cells of the retina were negative. At low dilutions, both sera stained nuclei of glial cells with a fine 


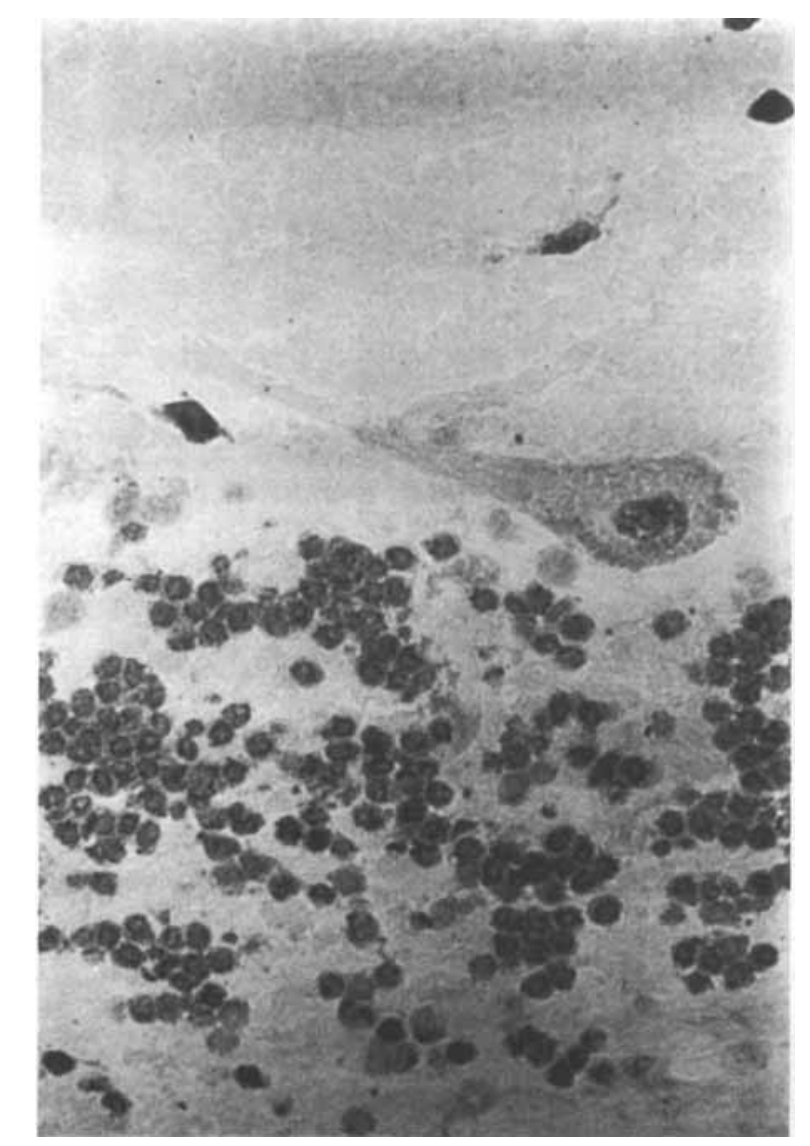

granular pattern, but at higher dilutions, only the neuronal staining was evident by IIF. The cytoplasm of most neurons was positive by immunoperoxidase, but the intensity of the staining was less than that of the nucleus (figure 3 ).

Both sera (dilution 1:50) were negative when tested by IIF on several adult normal tissue sections (thyroid, pancreas, colon, spleen, liver, adrenal, testis, kidney, and lymph node). Only weak staining of the nuclei of the spermatogonia of the testes was obtained with the serum of the patient with the higher titer.

In normal nonneural fetal tissues (adrenal, liver, colon, pancreas, stomach, spleen, testis, and kidney), the serum of one patient reacted at low titer (dilution 1:50) with the nuclei of cells in the medulla of the adrenal and in some germinal cells in the testis. The serum of the other patient, who had the higher titer, was positive in the nuclei, with a fine granular pattern in most of the sections tested. The staining disappeared at serum dilutions between 1:200 and 1:500, except for the reactivity in some germinal cells of the testis (figure 4). Nuclei in the fetal brain sections were positive, with a titer similar to that found in the adult brain.
Antibody characteristics. In both sera, a positive response was obtained with antihuman IgG, kappa, and lambda, suggesting that the antibody is a polyclonal IgG. In both sera, the antibody fixed the $\mathrm{C}_{3}$ fraction of complement, as demonstrated by a positive test for complement fixation using DRG and frontal cortex sections. The antibody reactivity was not species-specific; both sera stained nuclei of neurons of rat, mouse, pig, and guinea pig. Cytoplasmic staining, even by IIF, was more prominent in the brain sections of the guinea pig. Absorption of both sera with mouse liver powder or histones from liver and brain failed to abolish the reactivity against the nuclei of neurons, glial cells, or cells in the fetal testis. On the other hand, the reactivity in those areas was completely abolished by incubation of both sera with a nuclear-rich pellet from human cerebral cortex.

Antigen characteristics. Nuclear staining was removed by pretreating the sections with pronase $0.1 \mathrm{~N}$ $\mathrm{HCl}$ or heating to $100{ }^{\circ} \mathrm{C}$. Staining was preserved after pretreatment with alcohol, DNase I, or heating to $60{ }^{\circ} \mathrm{C}$. Pretreatment with RNase A decreased the titer of the antibody only onefold in both sera. These findings suggest that the antigen is a protein. Counterimmunoelectrophoresis failed to show precipitation lines between both sera and reference sera for Sm, nRNP, Ro, or La antibodies. ${ }^{b}$

Specificity of the antibody. By IIF, serum (dilution 1:50) from 2 of 25 normal healthy adults, 2 of 19 patients with lung carcinoma ( 5 with small cell type), 2 of 12 patients with breast carcinoma, 0 of 10 patients with malignant glioma, and 0 of 10 patients with several neurologic remote effects (paraneoplastic ataxia in 3 patients, mixed neuropathy, Guillain-Barré syndrome, Eaton-Lambert syndrome, necrotic myelopathy, motoneuron disease, opsoclonus, and optic neuropathy) had positive staining of the nuclei of neurons, buit the same reactivity was observed in glial cells and in sections of human kidney. None reacted at serum dilutions higher than 1:100.

Discussion. We found an antibody against a nuclear antigen in two patients with SSN. The antigen is not known, but the distribution of antibody reactivity and effects of pretreatment of brain sections were identical in both patients, implicating one nuclear antigen.

Unlike common antinuclear antibodies that react with antigens in all types of cells, the antibody in these patients was restricted in human tissues against an antigen in the nuclei of neurons. At high concentrations, the antibody also recognized an antigen in the nuclei of glial cells and fetal tissues, probably the same as the one in neuronal nuclei because serum no longer reacted with fetal tissues after absorption with nuclei of neural tissue.

The antigen seems to be a nuclear protein. The source of the weaker cytoplasmic staining is not certain; perhaps it is a result of transport of the nuclear protein to the cytoplasm. Alternately, the cytoplasmic 

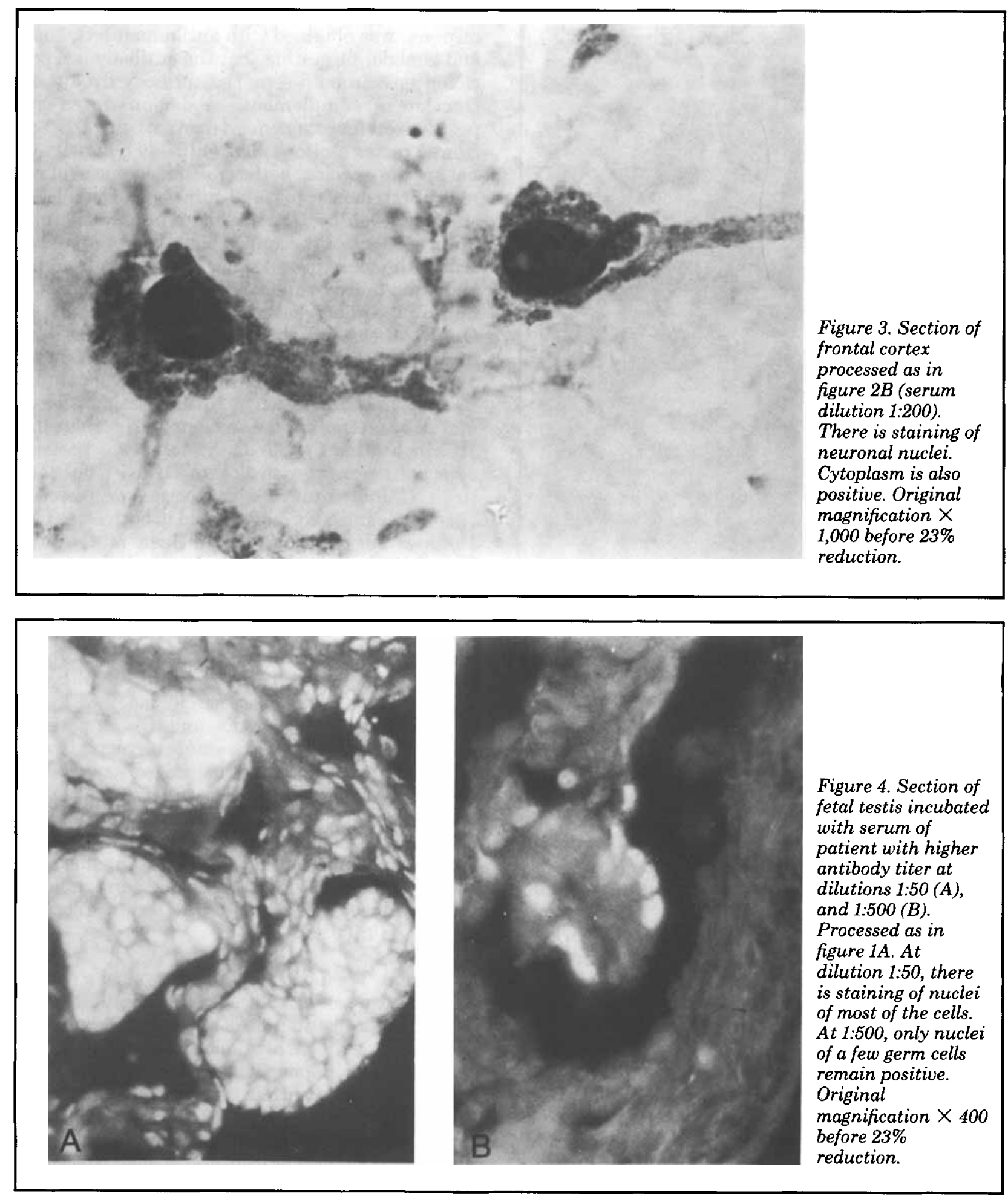

staining might be due to some other protein. Leaching of the nuclear antigen during the washing procedures seems unlikely because some neurons (Purkinje) had little or no cytoplasmic staining.

The antibody seems to be related to SSN. As previously reported, ${ }^{8}$ we found nuclear staining in brain sections when serum from normal subjects or patients with different diseases was studied, but in none of them was reactivity found in dilute serum or restricted to the neurons. If our results are confirmed in more patients, this antibody might be a marker for SSN.

The origin of the antibody is unknown. A simple 
immunologic response to neuronal damage is unlikely, because both patients probably have the same antibody in high titers, and no other antinuclear or cytoplasmic antibodies were demonstrated. The antibody could be directed against antigens shared by the tumor and the CNS, as reported in small cell carcinoma of the lung and other tumors. ${ }^{9.11}$ On the other hand, we found no reactivity in frozen sections of four small cell carcinomas of the lung from patients without neurologic remote effects incubated with the serum of both patients and stained with IIF. We have not yet been able to test a tumor from a patient who has either the antibody or SSN, or both. Lastly, the antibody may be directed against a virally induced nuclear antigen, as suggested by the $\mathrm{SSB} / \mathrm{La}^{12}$ antinuclear antibody. The immunoresponse could be triggered by viral infection, or some unknown factor might start an immune response against a latent virus (varicella-zoster herpesvirus?) in neurons of the DRG. ${ }^{13}$

This antibody seems to be restricted to SSN and may be important in the pathogenesis of this syndrome. The intracellular location of the antigen suggests that the antibody cannot cause the primary damage to the neuron because it could not penetrate the cell body in vivo. To demonstrate a causal relationship between the antibody and the cell damage, one must demonstrate that the antibody can damage neurons in culture, and that the disease can be reproduced when the antibody is injected into laboratory animals.

\section{Acknowledgments}

We are indebted to Dr. K. Elkon for performing the counterimmunoelectrophoresis studies, to Dr. P. Higgins for providing the purified histones, and to Dr. A. Houghton for his advice on the absorption studies and review of the manuscript.

\section{References}

1. Horwich MS, Cho L, Porro RS, Posner JB. Subacute sensory neuropathy: a remote effect of carcinoma. Ann Neurol 1977;2:7-19.

2. Henson RA, Urich H. Encephalomyelitis with carcinoma (chap 14). In: Cancer and the nervous system. Oxford, England: Blackwell Scientific Publications, 1982:314-45.

3. Wilkinson PC, Zeromski J. Immunofluorescent detection of antibodies against neurones in sensory carcinomatous neuropathy. Brain 1965;88:529-39.

4. Zeromski J. Immunological findings in sensory carcinomatous neuropathy. Application of peroxidase labelled antibody. J Experimental Immunology 1970;6:633-7.

5. Asbury AK, Johnson PC. Metabolic and toxic polyneuropathies (chap 4). In: Pathology of peripheral nerve. Philadelphia: WB Saunders, 1978:80-2.

6. Kurata N, Tan EM. Identification of antibodies to nuclear acidic antigens by counterimmunoelectrophoresis. Arthritis Rheum 1976:19:574-80.

7. Thompson RJ. Studies on RNA synthesis in two populations of nuclei from the mammalian cerebral cortex. J Neurochem 1973;21:19-40.

8. Watts H, Kennedy PGE, Thomas M. The significance of antineuronal antibodies in Alzheimer's disease. J Neuroimmunol 1981;1:107-16.

9. Bell CE, Seetharam S, McDaniel RC. Endodermally-derived and neural crest-derived differentiation antigens expressed by a human lung tumor. J Immunol 1976;116:1236-43.

10. Bell CE, Seetharam S. Identification of the Schwann cell as a peripheral nervous system cell possessing a differentiation antigen expressed by a human lung tumor. J Immunol 1977;118:826-31.

11. Bell CE, Seetharam S. Expression of endodermally derived and neural crest-derived differentiation antigens by human lung and colon tumours. Cancer 1979;44:13-8.

12. Lerner MR, Andrews NC, Miller G, Steitz JA. Two small RNAs encoded by Epstein-Barr virus and complexed with protein are precipitated by antibodies from patients with systemic lupus erythematosus. Proc Natl Acad Sci USA 1981;78:805-9.

13. Hyman RW, Ecker JR, Tenser RB. Varicella-zoster virus RNA in human trigeminal ganglia. Lancet 1983;2:814-6. 


\section{Neurology}

\section{Neuronal antinuclear antibody in sensory neuronopathy from lung cancer}

Francesc Graus, Carlos Cordon-Cardo and Jerome B. Posner

Neurology 1985;35;538

DOI 10.1212/WNL.35.4.538

This information is current as of April 1, 1985

\section{Updated Information \& Services}

Citations

Permissions \& Licensing

Reprints including high resolution figures, can be found at: http://n.neurology.org/content/35/4/538.full

This article has been cited by 10 HighWire-hosted articles:

http://n.neurology.org/content/35/4/538.full\#\#otherarticle s

Information about reproducing this article in parts (figures,tables) or in its entirety can be found online at: http://www.neurology.org/about/about_the_journal\#permi ssions

Information about ordering reprints can be found online: http://n.neurology.org/subscribers/advertise

Neurology ${ }^{\circledR}$ is the official journal of the American Academy of Neurology. Published continuously since 1951, it is now a weekly with 48 issues per year. Copyright $(C) 1985$ by Modern Medicine Publications, Inc.. All rights reserved. Print ISSN: 0028-3878. Online ISSN: 1526-632X.

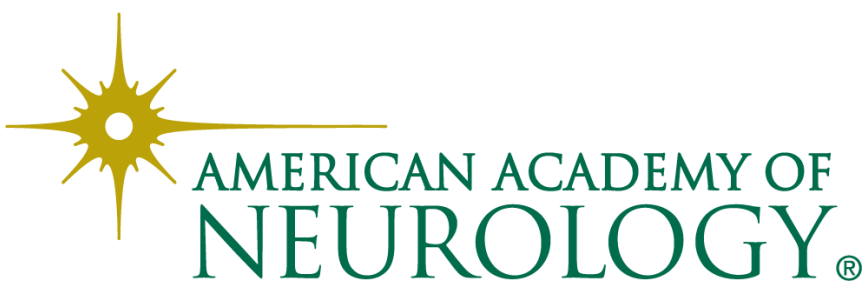

